OPEN ACCESS

Edited by:

Tamer Saad Kaoud,

University of Texas at Austin,

United States

Reviewed by:

Giulio Rossi,

Azienda Unità Sanitaria Locale (AUSL) della Romagna, Italy

Vassilis Georgoulias,

University of Crete, Greece

*Correspondence:

Fuyi Liu

liufuyi@zju.edu.cn

Specialty section:

This article was submitted to Molecular and Cellular Oncology,

a section of the journal

Frontiers in Oncology

Received: 28 November 2021 Accepted: 07 February 2022

Published: 25 February 2022

Citation:

Fu Z, Zhu G, Wang L, Hu S, Cheng L and Liu F (2022) Case Report: A Pregnant Woman Diagnosed as

ALK-Rearrangement Lung

Large Cell Neuroendocrine Cancer With Brain Metastasis.

Front. Oncol. 12:823813. doi: 10.3389/fonc.2022.823813

\section{Case Report: A Pregnant Woman Diagnosed as ALK-Rearrangement Lung Large Cell Neuroendocrine Cancer With Brain Metastasis}

\author{
Zaixiang Fu' ${ }^{1}$, Ganggui Zhu ${ }^{1}$, Liquan Wang ${ }^{2}$, Shen $\mathrm{Hu}^{2}$, Lu Cheng ${ }^{3}$ and Fuyi Liu ${ }^{1 *}$ \\ ${ }^{1}$ Department of Neurosurgery, Second Affiliated Hospital, School of Medicine, Zhejiang University, Hangzhou, China, \\ 2 Department of Obstetrics, Second Affiliated Hospital, School of Medicine, Zhejiang University, Hangzhou, China, \\ ${ }^{3}$ Department of Pathology, Second Affiliated Hospital, School of Medicine, Zhejiang University, Hangzhou, China
}

Concomitant malignant tumors and pregnancy present many difficult questions to both clinicians and patients. Due to no specific guidelines, each aspect of clinical management requires special considerations. This current report presents a rare case of a 38-year-old pregnant woman at gestational age 33 weeks with complaints of weakness of her right limbs for 2 weeks. After successive cesarean section and craniotomy, a diagnosis of lung large cell neuroendocrine carcinoma (LCNEC) metastatic to the brain was eventually made. Next generation sequencing (NGS) showed ALK-EML4 gene fusion. Immediately afterwards she was started on the targeted therapy with the ALK inhibitor alectinib. Ten months later, all known lesions exhibited a rapid regression, and no new brain metastases were found. Consequently, the therapeutic effect was considered as a partial response. Then, we review the previous literature using PubMed on maternal malignant brain tumors diagnosed during pregnancy, or lung LCNEC associated with ALK fusion, or ALK inhibitors treatment among the pregnant women, eventually, and discuss the concerns of dealing with these patients.

Keywords: ALK rearrangement, ALK inhibitors, alectinib, large cell neuroendocrine carcinoma, pregnancy, brain tumor, NGS

\section{INTRODUCTION}

It is very rare for a woman diagnosed as lung cancer with brain metastasis during pregnancy. Because of the special physiological condition of the mother and fetus and the low prevalence of such tumors, no standard treatment guidelines are published. Pulmonary large cell neuroendocrine carcinoma (LCNEC) is a rare subtype of lung cancer with aggressive behavior and poor prognosis, and the incidence appeared to be approximately $3 \%$ in a series of surgically resected cases (1). Anaplastic lymphoma kinase (ALK) fusion genes can be detected in approximately 5\%-6\% of all non-small cell lung cancer (NSCLC) patients, especially lung adenocarcinoma (2), thus, there are fewer patients with ALK rearrangement in LCNEC. To our knowledge, no studies have reported ALK rearrangement lung LCNEC with brain metastasis during pregnancy. Herein, we describe such a case and review the related literature. 


\section{CASE PRESENTATION}

A previously healthy 38-year-old woman (gravida 1 para 0 , frozen embryo transfer) who was 33 weeks pregnant was referred to the Obstetric Department of our hospital with a history of progressive numbness and weakness of her right limbs for 2 weeks. The day before admission, magnetic resonance imaging (MRI) was performed at the local hospital to consider neoplastic lesions in the left frontal lobe. Physical examination showed that the muscle strength of the right upper limb was grade 0 and the right lower limb was grade 3 . On the 1 st day of admission, the consultation of obstetrics, pediatrics and neurosurgery concluded that the patient was most likely to suffer from intracranial malignant tumor (metastasis or primary tumor). Since the fetus was in good condition at 33 weeks of gestation, it was proposed to promote fetal lung maturation at first, terminate the pregnancy by cesarean section at 34 weeks, and then perform craniotomy to remove the tumor as soon as possible. Considering the influence of contrast agent on the fetus, enhanced MRI examination was planned to be performed after termination of pregnancy. But the patient had rapid clinical deterioration. So an emergency cesarean section was performed under intravertebral anesthesia on the 2 nd day. A healthy baby boy was delivered safely. The fetus was preterm and no neonatal malformations were found. After delivery, contrast-enhanced MRI of brain showed a $30.3^{\star} 28.8 \mathrm{~mm}$ brain cystic solid mass in the left frontal lobe; accompanied by severe peritumoral edema; the solid and edge of lesion showed enhancement following administration of a contrast agent (Figure 1). On the 4th day, emergency craniotomy was performed because of the increased intracranial pressure, and then the patient was transferred to the Department of Neurosurgery. Macroscopically, the tumor is reddish in color and soft in texture with rich blood supply. The tumor was removed completely and sent for pathological examination. Immunohistochemistry (ICH) showed that TTF1, Syn, CgA, CD56, AE1/AE3, and CK7 were positive, while NapsinA, P40, PAX-8, and GATA-3 were negative (Figure 2). The Ki67 proliferation index was $70 \%$. Subsequently, a chest CT scan revealed a $45^{\star} 36^{\star} 50 \mathrm{~mm}$ tumor in the lower lobe of the left lung, and an abdominal CT showed a $39^{\star} 41 \mathrm{~mm}$ metastasis in the left adrenal gland (Figure 1). ECT demonstrated multiple bone metastases throughout the body (Figure 1). The pathological diagnosis was poorly differentiated neuroendocrine tumor, consistent with LCNEC, and the clinical stage was determined to be IV. In order to determine the optimal therapeutic strategy, next generation sequencing (NGS) of tumor samples and patient blood showed ALK-EML4 gene fusion with a mutation frequency of $29.21 \%$. Anti-ALK ICH was performed to confirm ALK protein expression (Figure 2). Therefore, the patient was treated with rehabilitation and alectinib, a novel highly selective inhibitor of ALK translocation. After 10 months of treatment with alectinib, the symptoms gradually improved, and radiological evaluation showed a dramatical shrinkage of all known lesions (Figure 1). At present, the patient is raising her child as normal at home and her performance status (PS) is 1 without any major adverse events.

\section{DISCUSSION}

The main characteristics of this case were: (1) the woman was diagnosed as a malignant intracranial tumor at 33 weeks of gestation and developed progressive neurological deterioration; (2) the tumor was pathologically diagnosed as LCNEC and NGS of ctDNA (circulation tumor DNA) showed EML4-ALK fusion; (3) the patient took alectinib treatment after delivery and the lesions shrunk dramatically.

Firstly, the incidence of most primary brain tumor in pregnancy seems not to be higher except for choriocarcinomas, meningiomas, and pituitary adenomas $(3,4)$. And there are no extracranial tumors that are likely to metastasize that are uniquely related to the specific pregnancy (5). But certain factors such as immunological tolerance, hormone-mediated growth, and hemodynamic changes may promote neoplasm growth mediating a common pathway to increasing intracranial mass effect $(3,4,6)$. Intracranial tumors usually initially present with symptoms and signs of increased intracranial pressure such as headache, dizziness, or vomiting, related focal neurological deficits and seizures, which are often confused with pregnancy itself, hypertensive disorders and thrombosis in pregnancy (7). Many of patients are misdiagnosed and fail to receive timely treatment. Therefore, it is vital for clinicians to pay attention to such patient with prolonged, non-remission and worsening symptoms during pregnancy to avoid ignoring the diagnosis of brain tumors. MRI is the preferred auxiliary examination because of its greater sensitivity, the best soft tissue visualization and lack of ionizing radiation. A gadolinium-containing contrast agent should be treated with caution, and it may be used only if the fetus and mother significantly benefit from it (8). In the acute setting, clinicians should not withhold head CTs. The fetal dose exposure from the maternal head CT is about 0.001-0.01 mGy which is lower than the minimum estimated threshold dose $(50$ mGy) (8).

In addition, due to the lack of level I or II evidence, most of comes from case reports and experts' opinions, so the development of treatment plan requires multidisciplinary collaboration between the obstetrician, neurosurgeon, anesthetist and so on. The major challenging questions include medical therapy, the timing of surgical intervention, the timing and type of delivery, and the mode of anesthesia. About medical management, steroids are the most important component of medical treatment, which can not only alleviate vasogenic cerebral edema and but also facilitate fetal lung maturity (9). Although long-term steroid use can contribute to neonatal hypoadrenalism, it is an uncommon complication (10). Mannitol has a risk of affecting fetal circulation, and doses of $0.5-1 \mathrm{~g} / \mathrm{kg}$ are considered safe (7). Additionally, prophylactic use of antiepileptic drugs is not recommended because of their teratogenicity. On the other hand, what we are most concerned about is the timing of surgery and delivery in pregnancy. In general, it depends on tumor type, gestational age, patient's clinical status and preferences. We reviewed the relevant literature, summarized the algorithm of N Kitchen (4) and Tewari et al (11), and made the following recommendations 


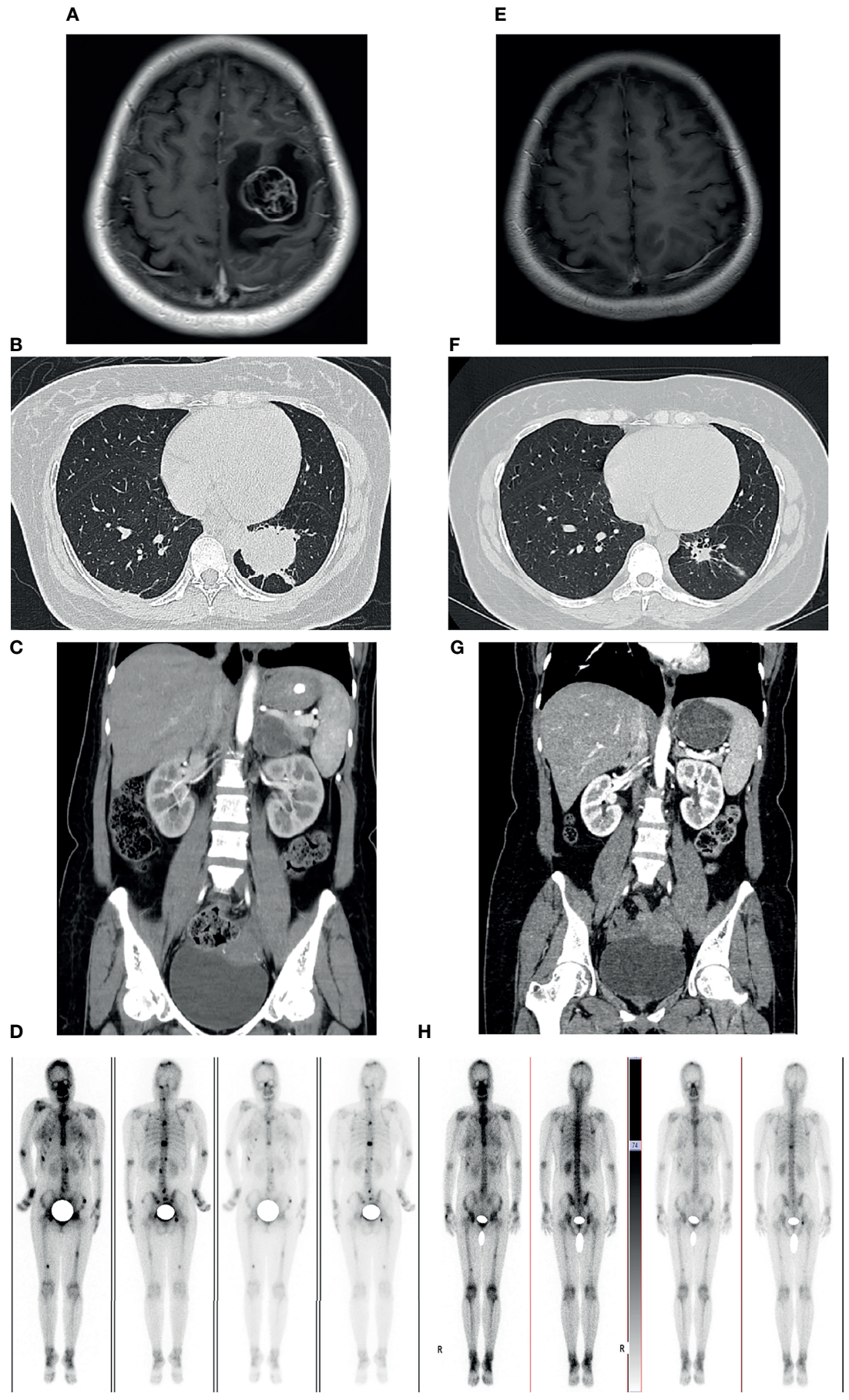

FIGURE 1 | Imaging examinations before craniotomy and alectinib treatment (A-D). 10-months follow-up radiological evaluation (E-H). (A) Contrast-enhanced cranial MRI showed the lesion in the left frontal lobe. (B) CT scan of the chest showing the mass in left lower lobe of the lung. (C) CT enhancement scan showing the mass in the left adrenal. (D) 99mTc-MDP bone scintigraphy demonstrating multiple lesions of increased activity in spine, pelvis, skull, ribs, skull and femurs. (E-H) Radiological evaluation demonstrating a dramatical shrinkage of all known lesions after 10 months.

for patients of an antenatal malignant symptomatic brain tumor (1). If the patient is in the early first trimester of pregnancy, a therapeutic abortion may be an option, since the risks of surgery, radiation therapy or chemotherapy are too high to the fetus while delayed treatment may be unsafe for the mother $(2,9)$. In stable patients presenting in the first or early second trimester, with a strong desire to continue the pregnancy, gestational advancement may be permitted to the early second trimester 

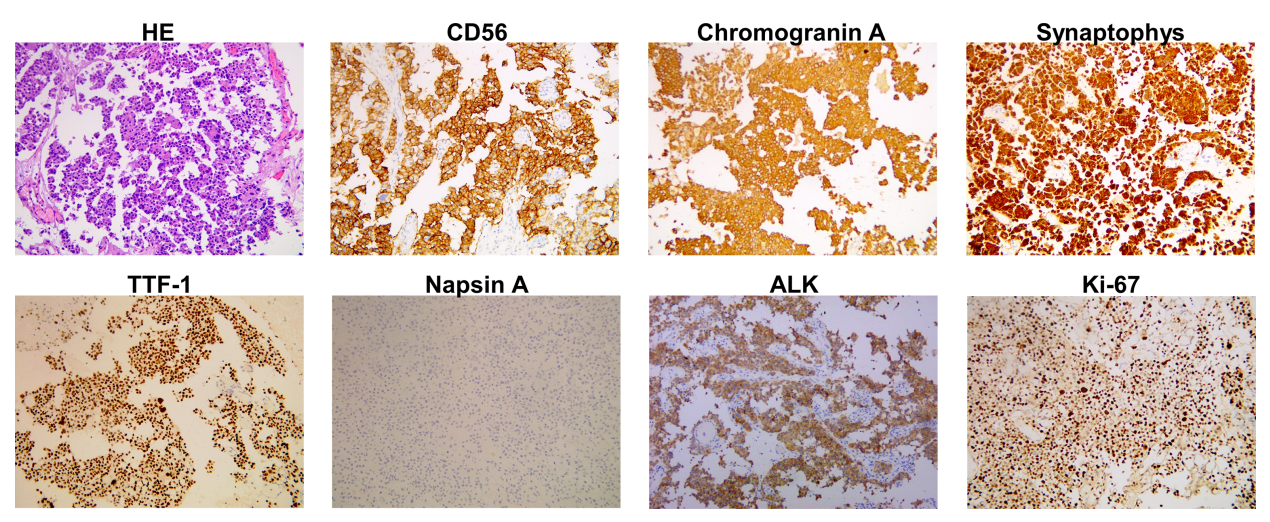

FIGURE 2 | Histopathological findings of the tumor in left frontal lobe. Haematoxylin and eosin (HE) staining is shown. Immunostaining indicated positivity for CD56, chromogranin A, synaptophys, thyroid transcription factor-1 (TTF-1), ALK, and negative for napsin A. The Ki67 staining index is $70 \%$.

prior to neurosurgery and radiotherapy. Unstable patients require emergency craniotomy and the risk of fetal loss must be clarified (3). The ideal time for surgical intervention seems to be the second trimester because of fetal vulnerability during the first and increased maternal intravascular volume in the third trimester (12). In the late second trimester and third trimester, stable patients should be closely monitored until fetal maturity. Patients presenting with deteriorating neurological function may be treated with radiotherapy as an option to delay surgery. For unstable patients with a risk of brain herniation, a cesarean section should be performed under general anesthesia, followed by immediately surgical decompression and tumor resection (4). Most obstetricians and neonatologists will postpone delivery until 32 or even 34 weeks of gestation, if possible, to ensure maturity and survival of the fetus.
Secondly, an ALK rearrangement generally occurs in lung adenocarcinoma, accounting for 5\%-6\% of all NSCLC cases, and is associated with younger age (median age of diagnosis of 55), and non-smoking or less smoking (2). Lung LCNEC is a rare subgroup of pulmonary neuroendocrine carcinoma with high malignancy and a dismal prognosis, appears to be more common in male, older, and heavy smokers (1). We searched the PubMed database and reviewed the previous and this case reports about lung LCNEC patients with ALK rearrangement (13-20) (Table 1). Of the ten cases, we found that the median age was 45.5 years (range $=32-75$ years), $60 \%$ were women, and $40 \%$ were smokers, which did not show a clear tendency to clinical features, perhaps related to too few cases. Interestingly, 9 of these 10 cases were from Asiatic patients (Table 1). However, no a definite racial difference for ALK rearrangement has been reported (21).

TABLE 1 | List of cases reported to have lung LCNEC with ALK rearrangement.

\begin{tabular}{|c|c|c|c|c|c|c|c|c|c|c|c|}
\hline No & $\begin{array}{l}\text { The first } \\
\text { author }\end{array}$ & Year & $\begin{array}{l}\text { Age/ } \\
\text { sex }\end{array}$ & Nation & $\begin{array}{l}\text { Smoking } \\
\text { status }\end{array}$ & ALK detection & $\begin{array}{l}\text { Fusion } \\
\text { genes }\end{array}$ & $\begin{array}{l}\text { Clinical } \\
\text { stage }\end{array}$ & $\begin{array}{l}\text { ALK Inhbitor } \\
\text { Therapy }\end{array}$ & $\begin{array}{l}\text { Clinical } \\
\text { outcome }\end{array}$ & $\begin{array}{c}\text { PFS } \\
\text { (Months) }\end{array}$ \\
\hline 1 & Omachi (13) & 2014 & $43 / F$ & Japan & $\mathrm{N}$ & $\begin{array}{l}\text { IHC, FISH, RT- } \\
\text { PCR }\end{array}$ & EML4 & IV & Crizotinib & Progression & 1.4 \\
\hline 2 & Hoton (15) & 2017 & $69 / F$ & Turkey & $\mathrm{N}$ & $\mathrm{FISH}$ & NA & IV & $\begin{array}{l}\text { Crizotinib } \\
\text { Ceritinib }\end{array}$ & $\begin{array}{l}\text { Progression } \\
\text { Progression }\end{array}$ & $\begin{array}{l}\text { 6(Crizotinib) } \\
\text { 9(Ceritinib) }\end{array}$ \\
\hline 3 & Hayashi (14) & 2017 & $75 / F$ & Japan & $\mathrm{N}$ & $\mathrm{FISH}$ & NA & $\mathrm{IVb}$ & Alectinib & $\mathrm{PR}$ & $6+$ \\
\hline 4 & Zheng (16) & 2018 & $44 / \mathrm{M}$ & China & $Y$ & $\mathrm{FISH}$ & NA & $\mathrm{IVb}$ & $N$ & NA & NA \\
\hline 5 & Zheng (16) & 2018 & $47 / F$ & China & $\mathrm{N}$ & $\| H C, N G S$ & EML4 & IVa & Crizotinib & $\mathrm{PR}$ & $10+$ \\
\hline 6 & Shimizu (17) & 2018 & $73 / \mathrm{M}$ & Japan & Y & FISH, RT-PCR & KIF5B & $\mathrm{IVb}$ & $\begin{array}{l}\text { Crizotinib } \\
\text { Alectinib }\end{array}$ & $\begin{array}{l}\text { Progression } \\
\text { SD }\end{array}$ & $\begin{array}{l}8 \text { (Crizotinib) } \\
4+\text { (Alectinib) }\end{array}$ \\
\hline 7 & Wang (20) & 2019 & $41 / \mathrm{M}$ & China & $Y$ & IHC, FISH, NGS & PLB1 & $\mathrm{IVb}$ & $\begin{array}{l}\text { Crizotinib } \\
\text { Anlotinib } \\
\text { Ceritinib }\end{array}$ & Progression & $\begin{array}{l}5 \text { (Crizotinib) } \\
1.4(\text { Anlotinib) } \\
4.5 \text { (Ceritinib) }\end{array}$ \\
\hline 8 & Tashiro (18) & 2020 & $32 / F$ & Japan & $Y$ & $\| \mathrm{HC}, \mathrm{FISH}$ & NA & $\mathrm{IVb}$ & Alectinib & Progression & 11 \\
\hline 9 & Masuda (19) & 2021 & $72 / \mathrm{M}$ & Japan & $\mathrm{N}$ & $\mathrm{IHC}, \mathrm{FISH}$ & NA & IV & Alectinib & $\begin{array}{l}\text { PR } \\
\text { Progression }\end{array}$ & $\begin{array}{l}1+ \\
4\end{array}$ \\
\hline 10 & This case & 2021 & $38 / F$ & China & $\mathrm{N}$ & NGS, IHC & EML4 & IV & Alectinib & PR & $10+$ \\
\hline
\end{tabular}

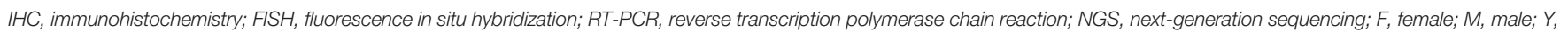

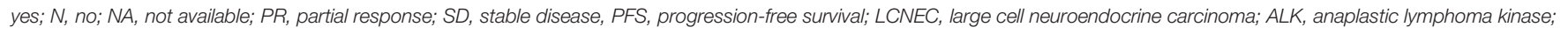
EML4, echinoderm microtubule-associated protein-like 4; KIF5B, the kinesin family 5B gene; PLB1, phospholipase B1. 
Instead, epidermal growth factor receptor (EGFR)-activating mutations are more common in East Asians (22, 23). Additionally, these oncogenic driver mutations, including EGFR, ALK, VEGF, HER2, c-KIT and so on, have been reported in LCNEC patients in some literature, particularly in Asiatic patients (24-26). But up to now LCNEC has remained poorly characterized due to its rarity. Therefore, further studies on the relationship between the molecular characteristics such as ALK rearrangement and clinical features of LCNEC may be needed. On the other hand, in contrast to pure NSCLC or LCNEC, we found NSCLC with neuroendocrine differentiation is a distinct and controversial entity (27). Unlike neuroendocrine carcinoma, hematoxylin and eosin (HE) findings of these tumors do not show a neuroendocrine phenotype, while immunohistochemical stains can indicate positivity for neuroendocrine markers such as chromogranin A, synaptophys or CD56 (27). However, on the basis of the current evidence, there is no clear relationship between neuroendocrine differentiation in NSCLC and prognostic implications $(27,28)$. Of note, Caumont et al. (29) reported a case of ALKrearrangement pulmonary adenocarcinoma treated with ALK inhibitor (ALK-I) crizotinib that produced neuroendocrine transformation associated with acquired resistance to crizontinib, but Sim et al. (30) found the tumor might be responsive to second generation ALK-Is, which was consistent with case report of Mengoli et al. (31).

Currently, the main diagnostic approaches used to detect ALK fusion include IHC, fluorescence in situ hybridization (FISH), RT-PCR, NGS. To date, FISH remains the "gold standard" for diagnosis. But these methods have their own limitations, such as IHC is unable to demonstrate ALK status directly (32), FISH has the disadvantages of operator-dependent, signal instability and low sensitivity $(32,33)$, and RT-PCR requires high quality RNA (32) and cannot detect unknown fusion partners $(32,34)$. For instance, because of the physiological expression of ALK in nerve cells, Takeuchi (35) considered that ALK rearrangement by ICH sometimes could be false positive in some lung cancers with neuroendocrine differentiation (30), particularly in LCNEC (36). In contrast, NGS has the highest specificity (37), is increasingly cost effective (32), detect multiple genetic alterations, regardless of known or unknown ALK fusions $(32,33,37)$, and can be used with solid or liquid biopsies $(38,39)$. Therefore, we speculate that NGS will gradually change the standard of ALK testing, especially detect mutations of resistance to ALK-Is.

Thirdly, the co-existence of ALK positive lung cancer and pregnancy is a rare condition. To date, there are no data to assess the molecular and genomic characteristics of these patients. In the USA, many ALK-Is such as crizotinib, alectinib, brigatinib, and ceritinib have been approved for the first line of therapy (40). But little information is available on the efficacy, fetal side effects, and gestational complications of these ALK-Is in pregnant patients. A single-institution, retrospective study published by Dagogo-Jack et al. found that of the eight pregnant women with lung cancer between 2009 and 2015, six had an ALK rearrangement and received ALK-Is treatment after delivery (41). Furthermore, we summarized 9 patients from previous and this case reports (42-49) (Table 2) and ALK-Is were used after delivery on six patients. These patients produced very positive results, similar to those of nonpregnant patients, thus we speculate ALK-Is treatment may be successfully used after delivery $(43,50)$. Significantly, of the nine patients, two were treated with crizotinib for a short period of time at the late pregnancy stage $(48,49)$, while only one received treatment with alectinib during the entire pregnancy (47). No evidence of abnormal fetal development due to ALK-Is during pregnancy was found. Nevertheless, we cannot exclude some unknown and delayed risks to child development, which requires longer follow-up.

\section{CONCLUSIONS}

It is a real challenge for clinicians to manage malignant intracranial tumors in pregnant patients, attempting to decide

TABLE 2 | List of pregnant women reported to have lung cancer with ALK rearrangement.

\begin{tabular}{|c|c|c|c|c|c|c|c|c|c|c|c|}
\hline No & $\begin{array}{l}\text { The first } \\
\text { author }\end{array}$ & Year & Age & Nation & $\begin{array}{l}\text { Timing of diagnosis } \\
\text { (weeks) }\end{array}$ & $\begin{array}{l}\text { Delivery } \\
\text { (weeks) }\end{array}$ & Pathology & $\begin{array}{l}\text { TKI treat- } \\
\text { ment }\end{array}$ & Timing of TKI & $\begin{array}{l}\text { Clinical } \\
\text { outcome }\end{array}$ & $\begin{array}{c}\text { PFS } \\
\text { (months) }\end{array}$ \\
\hline 1 & Neves (45) & 2014 & 36 & Portugal & 27 & 29 & $A D$ & Crizotinib & After delivery & SD & 9 \\
\hline 2 & Sariman (46) & 2013 & 34 & Turkey. & After delivery & 28 & $A D$ & Crizotinib & After delivery & SD & $6+$ \\
\hline 3 & Komura (44) & 2018 & 28 & Japan & After delivery & 37 & $A D$ & Alectinib & After delivery & PR & $12+$ \\
\hline 4 & Bellido (43) & 2019 & 42 & Spain & 30 & 30 & $A D$ & $\begin{array}{l}\text { Crizotinib } \\
\text { Alectinib }\end{array}$ & Puerperium & $\begin{array}{l}\text { Progression } \\
\text { SD }\end{array}$ & $\begin{array}{c}2 \\
10+\end{array}$ \\
\hline 5 & $\begin{array}{l}\text { Acosta Rojas } \\
(42)\end{array}$ & 2020 & 31 & Spain & 23 & 32 & $A D$ & Crizotinib & After delivery & Progression & 60 \\
\hline 6 & Scarfone (47) & 2021 & 31 & Italy & Before pregnancy & 35 & NA & Alectinib & Before pregnancy & PR & $32+$ \\
\hline 7 & Padrao (48) & 2018 & 36 & Portugal & 22 & 30 & $A D$ & $\begin{array}{l}\text { Crizotinib } \\
\text { Ceritinib }\end{array}$ & $\begin{array}{l}26 \text { weeks of } \\
\text { gestation }\end{array}$ & $\begin{array}{l}\text { Progression } \\
\text { Died }\end{array}$ & $\begin{array}{l}4 \\
2\end{array}$ \\
\hline 8 & Jensen (49) & 2019 & 32 & Denmark & 20 & 26 & $A D$ & Crizotinib & $\begin{array}{l}23 \text { weeks of } \\
\text { gestation }\end{array}$ & $\begin{array}{l}\text { SD } \\
\text { Died }\end{array}$ & $\begin{array}{l}3 \\
4\end{array}$ \\
\hline 9 & This case & 2021 & 38 & China & After delivery & 33 & LCNEC & Alectinib & Puerperium & $\mathrm{PR}$ & $10+$ \\
\hline
\end{tabular}

AD, Adenocarcinoma; ALK, anaplastic lymphoma kinase; TKI,tyrosine kinase inhibitors; $Y$, yes; N, no; NA, not available; PR, partial response; SD, stable disease; PFS, progression-free survival. 
on the optimal strategy to minimize the risk to the mother and fetus. Specialized medical teams with abundant experience and multidisciplinary discussions from the perspectives of the patient's clinical characteristics as well as preferences are paramount to develop individualized and the best approach. Based on previous reports, even though ALK rearrangement is a relatively rare event in patients with lung LCNEC and/or pregnancy, this phenomenon demonstrated that driver mutations tests are also necessary and NGS may become a mainstream approach in the future. ALK-Is seem to be used successfully after delivery according to some previous case reports. There have been no reports about major fetal side effects or pregnancy complications with ALK-Is during pregnancy or the peripartum period, highlighting the necessity for further investigation.

\section{DATA AVAILABILITY STATEMENT}

The original contributions presented in the study are included in the article/supplementary material. Further inquiries can be directed to the corresponding author.

\section{REFERENCES}

1. Fasano M, Della Corte CM, Papaccio F, Ciardiello F, Morgillo F. Pulmonary Large-Cell Neuroendocrine Carcinoma: From Epidemiology to Therapy. J Thorac Oncol (2015) 10(8):1133-41. doi: 10.1097/JTO.0000000000000589

2. Du X, Shao Y, Qin HF, Tai YH, Gao HJ. ALK-Rearrangement in Non-SmallCell Lung Cancer (NSCLC). Thorac Cancer (2018) 9(4):423-30. doi: 10.1111/ 1759-7714.12613

3. Ravindra VM, Braca JA3rd, Jensen RL, Duckworth EA. Management of Intracranial Pathology During Pregnancy: Case Example and Review of Management Strategies. Surg Neurol Int (2015) 6:43. doi: 10.4103/21527806.153845

4. Ng J, Kitchen N. Neurosurgery and Pregnancy. J Neurol Neurosurg Psychiatry (2008) 79(7):745-52. doi: 10.1136/jnnp.2007.117002

5. Simon RH. Brain Tumors in Pregnancy. Semin Neurol (1988) 8(3):214-21. doi: 10.1055/s-2008-1041380

6. Rodrigues AJ, Waldrop AR, Suharwardy S, Druzin ML, Iv M, Ansari JR, et al. Management of Brain Tumors Presenting in Pregnancy: A Case Series and Systematic Review. Am J Obstet Gynecol MFM (2021) 3(1):100256. doi: 10.1016/j.ajogmf.2020.100256

7. Molina-Botello D, Rodriguez-Sanchez JR, Cuevas-Garcia J, CardenasAlmaraz BV, Morales-Acevedo A, Mejia-Perez SI, et al. Pregnancy and Brain Tumors; A Systematic Review of the Literature. J Clin Neurosci (2021) 86:211-6. doi: 10.1016/j.jocn.2021.01.048

8. AOCG Committee on Obstetric Practice. Committee Opinion No. 723: Guidelines for Diagnostic Imaging During Pregnancy and Lactation. Obstet Gynecol (2017) 130(4):e210-e6. doi: 10.1097/AOG.0000000000002355

9. Bonfield CM, Engh JA. Pregnancy and Brain Tumors. Neurol Clin (2012) 30 (3):937-46. doi: 10.1016/j.ncl.2012.04.003

10. Trainer PJ. Corticosteroids and Pregnancy. Semin Reprod Med (2002) 20 (4):375-80. doi: 10.1055/s-2002-36710

11. Tewari KS, Cappuccini F, Asrat T, Flamm BL, Carpenter SE, Disaia PJ, et al. Obstetric Emergencies Precipitated by Malignant Brain Tumors. Am J Obstet Gynecol (2000) 182(5):1215-21. doi: 10.1016/s0002-9378(00)70188-8

12. van Westrhenen A, Senders JT, Martin E, DiRisio AC, Broekman MLD. Clinical Challenges of Glioma and Pregnancy: A Systematic Review. J Neurooncol (2018) 139(1):1-11. doi: 10.1007/s11060-018-2851-3

13. Omachi N, Shimizu S, Kawaguchi T, Tezuka K, Kanazu M, Tamiya A, et al. A Case of Large-Cell Neuroendocrine Carcinoma Harboring an EML4-ALK

\section{ETHICS STATEMENT}

Written informed consent was obtained from the individual(s) for the publication of any potentially identifiable images or data included in this article.

\section{AUTHOR CONTRIBUTIONS}

ZF drafted the manuscript and performed the literature review. GZ, LW, and SH retrieved the clinical and the image information. LC provided and analyzed the pathological information. FL designed the study and revised the manuscript. All authors contributed to the article and approved the final version of the manuscript.

\section{ACKNOWLEDGMENTS}

We are grateful to the work of colleagues in the Pathology Department in offering the original images. We acknowledge the patient's contributions to the study.

Rearrangement With Resistance to the ALK Inhibitor Crizotinib. J Thorac Oncol (2014) 9(6):e40-2. doi: 10.1097/JTO.0000000000000103

14. Hayashi N, Fujita A, Saikai T, Takabatake H, Sotoshiro M, Sekine K, et al. Large Cell Neuroendocrine Carcinoma Harboring an Anaplastic Lymphoma Kinase (ALK) Rearrangement With Response to Alectinib. Intern Med (2018) 57(5):713-6. doi: 10.2169/internalmedicine.9368-17

15. Hoton D, Humblet Y, Libbrecht L. Phenotypic Variation of an ALK-Positive Large-Cell Neuroendocrine Lung Carcinoma With Carcinoid Morphology During Treatment With ALK Inhibitors. Histopathology (2018) 72(4):707-10. doi: $10.1111 /$ his. 13388

16. Zheng Q, Zheng M, Jin Y, Shen X, Shan L, Shen L, et al. ALK-Rearrangement Neuroendocrine Carcinoma of the Lung: A Comprehensive Study of a Rare Case Series and Review of Literature. Onco Targets Ther (2018) 11:4991-8. doi: 10.2147/OTT.S172124

17. Shimizu N, Akashi Y, Fujii T, Shiono H, Yane K, Kitahara T, et al. Use of ALK Immunohistochemistry for Optimal Therapeutic Strategy of Pulmonary Large-Cell Neuroendocrine Carcinoma and Identification of a Novel KIF5B-ALK Fusion Oncokinase. Anticancer Res (2019) 39(1):413-20. doi: 10.21873 /anticanres.13127

18. Tashiro T, Imamura K, Tomita Y, Tamanoi D, Takaki A, Sugahara K, et al. Heterogeneous Tumor-Immune Microenvironments Between Primary and Metastatic Tumors in a Patient With ALK Rearrangement-Positive Large Cell Neuroendocrine Carcinoma. Int J Mol Sci (2020) 21(24):9705. doi: 10.3390/ ijms21249705

19. Masuda K, Saiki M, Shimamura S, Ide S, Uchida Y, Sogami Y, et al. Dramatic Response to Alectinib in an ALK-Positive LCNEC Patient With a Poor Performance Status: A Case Report. Respirol Case Rep (2021) 9(9):e0817. doi: $10.1002 / \mathrm{rcr} 2.817$

20. Wang S, Wu X, Zhao J, Chen H, Zhang Z, Wang M, et al. Next-Generation Sequencing Identified a Novel Crizotinib-Sensitive PLB1-ALK Rearrangement in Lung Large-Cell Neuroendocrine Carcinoma. Clin Lung Cancer (2021) 22 (3):e366-e70. doi: 10.1016/j.cllc.2020.05.026

21. Martelli MP, Sozzi G, Hernandez L, Pettirossi V, Navarro A, Conte D, et al. EML4-ALK Rearrangement in non-Small Cell Lung Cancer and Non-Tumor Lung Tissues. Am J Pathol (2009) 174(2):661-70. doi: 10.2353/ ajpath.2009.080755

22. da Cunha Santos G, Shepherd FA, Tsao MS. EGFR Mutations and Lung Cancer. Annu Rev Pathol (2011) 6:49-69. doi: 10.1146/annurev-pathol011110-130206 
23. Sakurada A, Shepherd FA, Tsao MS. Epidermal Growth Factor Receptor Tyrosine Kinase Inhibitors in Lung Cancer: Impact of Primary or Secondary Mutations. Clin Lung Cancer (2006) 7 Suppl 4:S138-44. doi: 10.3816/ clc.2006.s.005

24. Ferrara MG, Stefani A, Simbolo M, Pilotto S, Martini M, Lococo F, et al. Large Cell Neuro-Endocrine Carcinoma of the Lung: Current Treatment Options and Potential Future Opportunities. Front Oncol (2021) 11:650293. doi: 10.3389/fonc.2021.650293

25. Iyoda A, Travis WD, Sarkaria IS, Jiang SX, Amano H, Sato Y, et al. Expression Profiling and Identification of Potential Molecular Targets for Therapy in Pulmonary Large-Cell Neuroendocrine Carcinoma. Exp Ther Med (2011) 2 (6):1041-5. doi: 10.3892/etm.2011.343

26. Lou G, Yu X, Song Z. Molecular Profiling and Survival of Completely Resected Primary Pulmonary Neuroendocrine Carcinoma. Clin Lung Cancer (2017) 18 (3):e197-201. doi: 10.1016/j.cllc.2016.11.014

27. Ionescu DN, Treaba D, Gilks CB, Leung S, Renouf D, Laskin J, et al. Nonsmall Cell Lung Carcinoma With Neuroendocrine Differentiation-An Entity of No Clinical or Prognostic Significance. Am J Surg Pathol (2007) 31(1):26-32. doi: 10.1097/01.pas.0000213319.04919.97

28. Segawa Y, Takata S, Fujii M, Oze I, Fujiwara Y, Kato Y, et al. Immunohistochemical Detection of Neuroendocrine Differentiation in Non-Small-Cell Lung Cancer and its Clinical Implications. J Cancer Res Clin Oncol (2009) 135(8):1055-9. doi: 10.1007/s00432-009-0544-1

29. Caumont C, Veillon R, Gros A, Laharanne E, Begueret H, Merlio JP. Neuroendocrine Phenotype as an Acquired Resistance Mechanism in ALKRearranged Lung Adenocarcinoma. Lung Cancer (2016) 92:15-8. doi: 10.1016/j.lungcan.2015.12.001

30. Sim J, Kim H, Hyeon J, Choi Y, Han J. Anaplastic Lymphoma Kinase (ALK)Expressing Lung Adenocarcinoma With Combined Neuroendocrine Component or Neuroendocrine Transformation: Implications for Neuroendocrine Transformation and Response to ALK-Tyrosine Kinase Inhibitors. J Korean Med Sci (2018) 33(15):e123. doi: 10.3346/jkms. 2018.33.e123

31. Mengoli MC, Bertolini F, Maur M, Barbieri F, Longo L, Gasparri P, et al. ALKPositive Adenocarcinoma of the Lung Expressing Neuroendocrine Markers and Presenting as a "Pituitary Adenoma". Pathologica (2017) 109(4):408-11.

32. Kozuma Y, Toyokawa G, Seto T. ALK Testing Methods: Is There a Winner or Loser? Expert Rev Anticancer Ther (2019) 19(3):237-44. doi: 10.1080/ 14737140.2019 .1562343

33. Chang WC, Kim HK, Shin BK. Clinicopathological Features and Diagnostic Methods of ALK Fusionpositive Nonsmall Cell Lung Cancer in Korea. Oncol Rep (2020) 43(1):218-28. doi: 10.3892/or.2019.7399

34. Wang B, Chen R, Wang C, Guo J, Yuan M, Chen H, et al. Identification of Novel ALK Fusions Using DNA/RNA Sequencing in Immunohistochemistry/ RT-PCR Discordant NSCLC Patients. Hum Pathol (2021) 114:90-8. doi: 10.1016/j.humpath.2021.05.005

35. Takeuchi K. Interpretation of Anti-ALK Immunohistochemistry Results. J Thorac Oncol (2013) 8(7):e67-8. doi: 10.1097/JTO.0b013e318293elff

36. Takeuchi K, Soda M, Togashi Y, Suzuki R, Sakata S, Hatano S, et al. RET, ROS1 and ALK Fusions in Lung Cancer. Nat Med (2012) 18(3):378-81. doi: $10.1038 / \mathrm{nm} .2658$

37. Li Y, Zhang R, Peng R, Ding J, Han Y, Wang G, et al. Reliability Assurance of Detection of EML4-ALK Rearrangement in Non-Small Cell Lung Cancer: The Results of Proficiency Testing in China. J Thorac Oncol (2016) 11(6):924-9. doi: 10.1016/j.jtho.2016.03.004

38. Sanchez-Herrero E, Serna-Blasco R, Ivanchuk V, Garcia-Campelo R, Domine Gomez M, Sanchez JM, et al. NGS-Based Liquid Biopsy Profiling Identifies Mechanisms of Resistance to ALK Inhibitors: A Step Toward Personalized
NSCLC Treatment. Mol Oncol (2021) 15(9):2363-76. doi: 10.1002/18780261.13033

39. Bruno R, Fontanini G. Next Generation Sequencing for Gene Fusion Analysis in Lung Cancer: A Literature Review. Diagnostics (Basel) (2020) 10(8):521 doi: 10.3390/diagnostics10080521

40. Xia B, Nagasaka M, Zhu VW, Ou SI, Soo RA. How to Select the Best Upfront Therapy for Metastatic Disease? Focus on ALK-Rearranged non-Small Cell Lung Cancer (NSCLC). Transl Lung Cancer Res (2020) 9(6):2521-34. doi: $10.21037 /$ tlcr-20-331

41. Dagogo-Jack I, Gainor JF, Porter RL, Schultz KR, Solomon BJ, Stevens S, et al. Clinicopathologic Features of NSCLC Diagnosed During Pregnancy or the Peripartum Period in the Era of Molecular Genotyping. J Thorac Oncol (2016) 11(9):1522-8. doi: 10.1016/j.jtho.2016.05.031

42. Acosta Rojas A, Collazo-Lorduy A, Remon J, Hernando Requejo O, JimenezMunarriz B, Rubio Rodriguez MC, et al. Lung Adenocarcinoma During Pregnancy: 11-Year Follow-Up. Case Rep Oncol (2020) 13(2):892-5. doi: $10.1159 / 000508360$

43. Bellido C, Barbero P, Forcen L, Blanco M, Alonso-Riano M, Galindo A. Lung Adenocarcinoma During Pregnancy: Clinical Case and Literature Review. J Matern Fetal Neonatal Med (2019) 32(19):3300-2. doi: 10.1080/ 14767058.2018.1461830

44. Komura M, Yagishita S, Nakamura K, Arano N, Takeshige T, Muraki K, et al. A Case of a Pregnant Woman Diagnosed as Having ALK-Rearranged Lung Adenocarcinoma. Vivo (2018) 32(5):1205-9. doi: 10.21873/invivo.11365

45. Neves I, Mota PC, Hespanhol VP. Lung Cancer During Pregnancy: An Unusual Case. Rev Port Pneumol (2014) 20(1):46-9. doi: 10.1016/ j.rppneu.2013.06.005

46. Sariman N, Levent E, Yener NA, Orki A, Saygi A. Lung Cancer and Pregnancy. Lung Cancer (2013) 79(3):321-3. doi: 10.1016/j.lungcan.2012.11.014

47. Scarfone G, Fumagalli M, Imbimbo M, Ceruti T, Cribiu FM, Di Loreto E, et al. First Case Report of Pregnancy on Alectinib in a Woman With Metastatic ALK-Rearranged Lung Cancer: A Case Report. J Thorac Oncol (2021) 16 (5):873-7. doi: 10.1016/j.jtho.2021.02.005

48. Padrao E, Melo C, Fernandes G, Magalhaes A. Lung Cancer in Pregnancy Report of a Case Treated With Crizotinib. Pulmonology (2018) 24(3):205-7. doi: 10.1016/j.pulmoe.2018.03.007

49. Jensen KH, Persson G, Storgaard L, Nielsen BB, Pedersen BW, Maroun LL, et al. Antineoplastic Treatment With Crizotinib During Pregnancy: A Case Report. Acta Oncol (2019) 58(1):121-2. doi: 10.1080/0284186X.2018.1497302

50. Rothschild SI. Lung Cancer in Pregnancy-A Forgotten Disease Entity. J Thorac Oncol (2016) 11(9):1376-8. doi: 10.1016/j.jtho.2016.07.009

Conflict of Interest: The authors declare that the research was conducted in the absence of any commercial or financial relationships that could be construed as a potential conflict of interest.

Publisher's Note: All claims expressed in this article are solely those of the authors and do not necessarily represent those of their affiliated organizations, or those of the publisher, the editors and the reviewers. Any product that may be evaluated in this article, or claim that may be made by its manufacturer, is not guaranteed or endorsed by the publisher.

Copyright (อ $2022 \mathrm{Fu}, \mathrm{Zhu}$, Wang, Hu, Cheng and Liu. This is an open-access article distributed under the terms of the Creative Commons Attribution License (CC BY). The use, distribution or reproduction in other forums is permitted, provided the original author(s) and the copyright owner(s) are credited and that the original publication in this journal is cited, in accordance with accepted academic practice. No use, distribution or reproduction is permitted which does not comply with these terms. 